\title{
VALIDATED SPECTROPHOTOMETRIC METHODS FOR THE DETERMINATION OF RALOXIFENE HYDROCHLORIDE IN PHARMACEUTICALS
}

\author{
K BASAVAIAH ${ }^{1 *}$ and U R ANIL KUMAR ${ }^{1}$, KALSANG THARPA ${ }^{1}$ and K B VINAY ${ }^{2}$
}

\author{
${ }^{1}$ Department of Chemistry, University of Mysore, Manasagangotri, Mysore 570 006, India \\ ${ }^{2}$ Department of Process Analytical Research, Advinus Therapeutics, Phase II,Peenya Industrial Area, Bangalore-560058, India. \\ (Received: March 17, 2008 - Accepted: May 29, 2008)
}

\begin{abstract}
Two new simple, precise, rapid and extraction-free spectrophotometric methods are proposed for the determination of raloxifene hydrochloride (RLX) using bromate-bromide mixture and two dyes, methylene blue and rhodamine B, as reagents. The methods entail the addition of a known excess of bromatebromide mixture to RLX in hydrochloric acid medium followed by determination of residual bromine by reacting with a fixed amount of either methylene blue and measuring the absorbance at $665 \mathrm{~nm}$ (Method A) or rhodamine B and measuring the absorbance at $555 \mathrm{~nm}$ (Method B). The amount of bromate reacted corresponds to the amount of RLX. In both the methods, the absorbance is found to increase linearly with the concentration of RLX. Under the optimum conditions, RLX could be assayed in the concentration ranges $0.5-5.0$ and $0.1-2.0 \mu \mathrm{g} \mathrm{mL}^{-1}$ from method A and method B, respectively. The apparent molar absorptivities are calculated to be $7.0 \times 10^{4}$ and $1.1 \times 10^{5} \mathrm{~L} \mathrm{~mol}^{-1} \mathrm{~cm}^{-1}$ for method A and method B, respectively, and the corresponding Sandell sensitivity values are 0.0073 and 0.0048 $\mu \mathrm{g} \mathrm{cm}^{-2}$. The limits of detection and quantification have also been reported for both the spectrophotometric methods. The overall reproducibility of the methods was excellent and recoveries were 98.3-102.5\% and 98.2-103.2\% for method A and method B, respectively. The proposed methods can be readily utilized for bulk drug and in pharmaceutical formulations.
\end{abstract}

Key words: Raloxifene hydrochloride, Assay, Spectrophotometry, Bomate-bromide, Formulations.

\section{INTRODUCTION}

Raloxifene hydrochloride (RLX) is a selective estrogen receptor modulator that belongs to the benzothiophene class of compounds ${ }^{1}$ (Fig.1). The chemical designation is methanone,[6-hdroxy-2-(4-hydroxyphenyl)benzo[b]thien-3yl]-[4-[2-(1-piperidinyl) ethoxy]phenyl]-, hydrochloride. RLX is used in the treatment and prevention of osteoporosis in post-menopausal women.

Literature on the methods for the determination of RLX in pharmaceuticals is scanty. High performance liquid chromatography (HPLC) has been used for the assay of RLX in bulk drug ${ }^{2}$ and in dosage forms ${ }^{3-7}$. Chen et al ${ }^{8}$ have recently proposed an UV-spectrophotometric method for determination of RLX in capsules. A quantitative assay method for RLX in pharmaceutical preparations by capillary electrophoresis ${ }^{9}$ has recently been reported. A some what sensitive method based on the measurement of the intensity of resonance rayleigh scattering (RRS) ${ }^{10}$ of the ion association complex of RLX with Evans Blue was developed by Fan et al. but, the method requires an expensive instrumental set up. Visible spectrophotometry, inspite of its simplicity, reasonable accuracy and precision, and speed, has not been widely applied for the assay of RLX. There are only two report on the visible spectrophotometric determination of RLX. Dharuman et al ${ }^{11}$ have proposed two methods. One method is based on the formation of bluish green chromogen formed when the drug is treated with ferric-ferricyanide reagent. The other involves the reduction of Fehling's reagent by RLX followed by measurement of blue-green species at $430 \mathrm{~nm}$. Very recently, Annapura et al ${ }^{12}$ have reported three procedures based on redox and complexation reactions. Some of the reported methods, however, suffer from such disadvantages as poor selectivity, sensitivity, accuracy and precision (Table 1). The present investigation aims to develop sensitive and cost-effective methods for the determination of RLX in pure form and in dosage forms using spectrophotometric technique. The methods utilize bromate-bromide mixture as oxidimetric reagent, which has successfully been used for the sensitive spectrophotometric determination of many bioactive substances ${ }^{13-21}$. The proposed method has the advantages of speed sensitivity and simplicity besides being accurate and precise, and can be adopted by the pharmaceutical laboratories for industrial quality control.

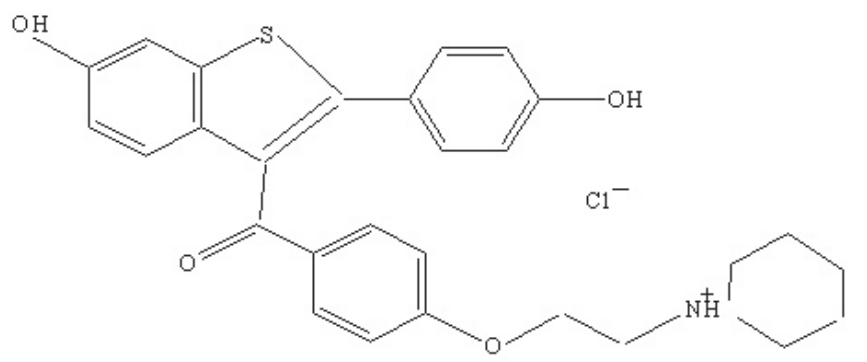

Fig 1. Structure of raloxifene hydrochloride

\section{EXPERIMENTAL}

\section{Apparatus}

A Systronics model 106 digital spectrophotometer with 1-cm matched quartz cells was used for all absorbance measurements.

Reagents and materials

All chemicals used were of analytical reagent grade and distilled water was used to prepare all solutions. A standard solution equivalent to $2 \mathrm{mM} \mathrm{KBrO}$ $-20 \mathrm{mM} \mathrm{KBr}$ was prepared by dissolving accurately weighed $3.34 \mathrm{~g}_{\text {of }} \mathrm{KBrO}_{3}$ (Sarabhai M. chemicals, Baroda, India) and $15.0 \mathrm{~g}$ of $\mathrm{KBr}$ ( S.d. Fine Chem. Ltd., Mumbai, India) in water and diluting to 1 liter in a volumetric flask. The above solution was diluted appropriately with water to get 25 and $10 \mu \mathrm{g}$ $\mathrm{mL}^{-1}$ concentrations for method $\mathrm{A}$ and method $\mathrm{B}$, respectively. To prepare 40 $\mu \mathrm{g} \mathrm{mL}-1$ methylene blue for method A, first, a $500 \mu \mathrm{g} \mathrm{mL}-1$ dye solution was prepared by dissolving $71.5 \mathrm{mg}$ of dye (Qualigen fine-chem., Mumbai, assay $70 \%$ ) in water and diluting to $100 \mathrm{~mL}$ in a calibrated flask, and filtered using glass wool. This was appropriately diluted to get the required concentration. For method B, first, a $500 \mu \mathrm{g} \mathrm{mL}^{-1}$ rhodamine B solution was prepared by dissolving $62.5 \mathrm{mg}$ of dye (s.d.fine-chem Ltd., Mumbai, $80 \%$ assay) in water and diluting to $100 \mathrm{~mL}$, and filtered. This was appropriately diluted with water to get $50 \mu \mathrm{g} \mathrm{mL}^{-1}$. Hydrochloric acid $(5 \mathrm{M})$ was prepared by diluting $43 \mathrm{~mL}$ of concentrated acid (s.d.fine-chem Ltd., Mumbai, Sp gr 1.18) to $100 \mathrm{~mL}$ with water. Pharmaceutical grade RLX, certified to be $99.8 \%$ pure was procured from Cipla India Ltd, Mumbai, India, and was used as received. A $1 \mathrm{mg} \mathrm{mL}^{-1}$ solution of RLX was prepared by dissolving accurately weighed $250 \mathrm{mg}$ of pure drug in $38 \mathrm{~mL}$ glacial acetic acid and warmed to get clear solution, followed by diluting to $250 \mathrm{~mL}$ with water in a calibrated flask. This stock solution (1000 $\left.\mu \mathrm{g} \mathrm{mL}^{-1}\right)$ was diluted with water to get working concentrations of 10 and $5 \mu \mathrm{g}$ $\mathrm{mL}^{-1} \mathrm{RLX}$ for method $\mathrm{A}$ and method $\mathrm{B}$, respectively. 
Table 1. Comparison of the proposed methods with the existing spectrophotometric and other methods.

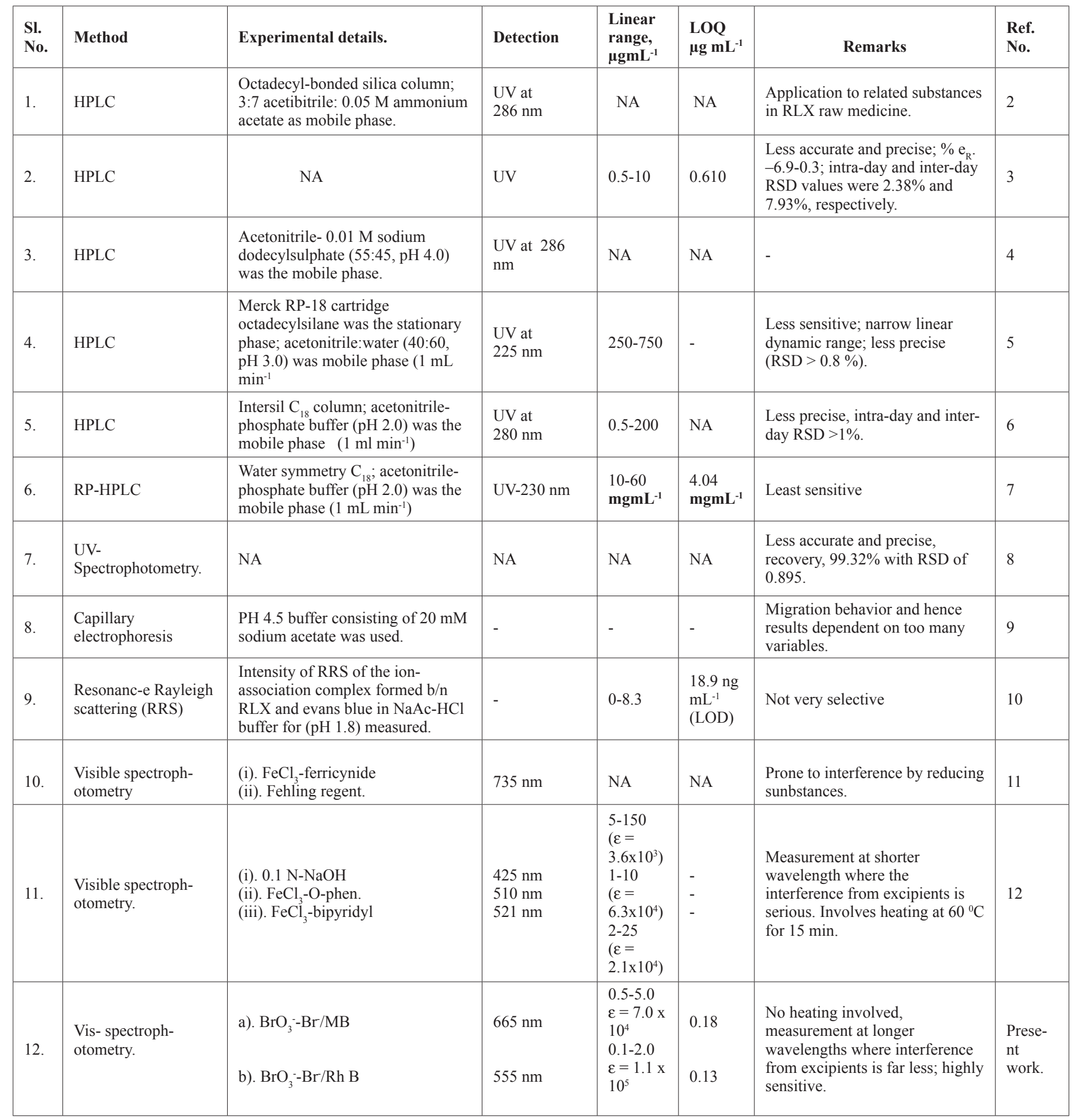

\section{Procedures}

Spectrophotometric method using methylene blue (Method A)

Aliquots of pure RLX solution ( 0.5 to $\left.5.0 \mathrm{~mL} ; 10 \mu \mathrm{g} \mathrm{mL}^{-1}\right)$ were transferred into a series of $10 \mathrm{~mL}$ calibrated flasks and the total volume was adjusted to $5.0 \mathrm{~mL}$ with water. To each flask were added $1 \mathrm{~mL}$ of $5 \mathrm{M}$ hydrochloric acid followed by $1 \mathrm{~mL}$ of bromate-bromide mixture $\left(25 \mu \mathrm{g} \mathrm{mL}{ }^{-1}\right.$ w.r.t $\left.\mathrm{KBrO}_{3}\right)$. The flasks were stoppered, content was mixed well and the flasks were set aside for $10 \mathrm{~min}$ with occasional shaking. Finally, $1 \mathrm{~mL}$ of $40 \mu \mathrm{g} \mathrm{mL}^{-1}$ methylene blue solution was added to each flask, diluted to the mark with water and the absorbance of solution was measured at $665 \mathrm{~nm}$ against reagent blank after $10 \mathrm{~min}$.

3.2. Spectrophotometry with rhodamine $B$ (Method B)

Varying aliquots $(0.2-4.0 \mathrm{~mL})$ of standard $5 \mu \mathrm{g} \mathrm{mL}^{-1} \mathrm{RLX}$ solution were measured accurately and delivered into a series of $10 \mathrm{~mL}$ calibrated flasks and the total volume was brought to $4.0 \mathrm{~mL}$ with water. To each flask were added 1 $\mathrm{mL}$ each of $5 \mathrm{M}$ hydrochloric acid and bromate-bromide mixture $\left(10 \mu \mathrm{g} \mathrm{mL}^{-1}\right.$ in $\mathrm{KBrO}_{3}$ ) successively; the flasks were stoppered, and let stand for 10 min with occasional shaking. Then, $1 \mathrm{~mL}$ of $50 \mu \mathrm{g} \mathrm{mL}{ }^{-1}$ rhodamine B solution was added 
to each flask, the volume was adjusted to the mark with water and mixed well. The absorbance of each solution was measured at $555 \mathrm{~nm}$ against a reagent blank after $10 \mathrm{~min}$.

In either spectrophotometric method, the concentration of the unknown was read from the calibration graph or computed from the regression equation derived from the Beer's law data.

Assay procedure for formulations

An amount of finely ground tablet powder equivalent to $100 \mathrm{mg}$ of RLX was accurately weighed into a beaker, $15 \mathrm{~mL}$ of glacial acetic acid was added and stirred for $20 \mathrm{~min}$ and warmed. Then, the volume was made up $100 \mathrm{~mL}$ in calibrated flask with water, mixed well, and filtered using a Whatman No 42 filter paper. First $10 \mathrm{~mL}$ portion of the filtrate was discarded and a suitable aliquot of the subsequent portion ( $\left.1 \mathrm{mg} \mathrm{mL}^{-1} \mathrm{RLX}\right)$ was diluted appropriately to get 10 and $5 \mu \mathrm{g} \mathrm{mL}^{-1}$ concentrations for analysis by spectrophotometric method A and method B, respectively.

\section{RESULTS AND DISCUSSION}

\section{Optimization of experimental conditions}

The proposed spectrophotometric methods are indirect and are based on the determination of the residual bromine (insitu generated) after allowing the reaction between RLX and a measured amount of bromine to be complete. The surplus bromine was determined by reacting it with a fixed amount of either methylene blue or rhodamine -B dye. The amount of bromine reacted corresponds to the amount of RLX, which forms the basis for the assay.

RLX when added in increasing concentrations to a fixed concentration of insitu generated bromine, consumes the latter proportionately and there occurs a concomitant fall in the concentrations of bromine. When a fixed concentration of dye is added to decreasing concentration of bromine, a concomitant increase in the concentration of dye results. Consequently, a proportional increase in the absorbance at the respective $\lambda_{\text {max }}$ is observed with increasing concentrations of RLX (fig.2 and 3).

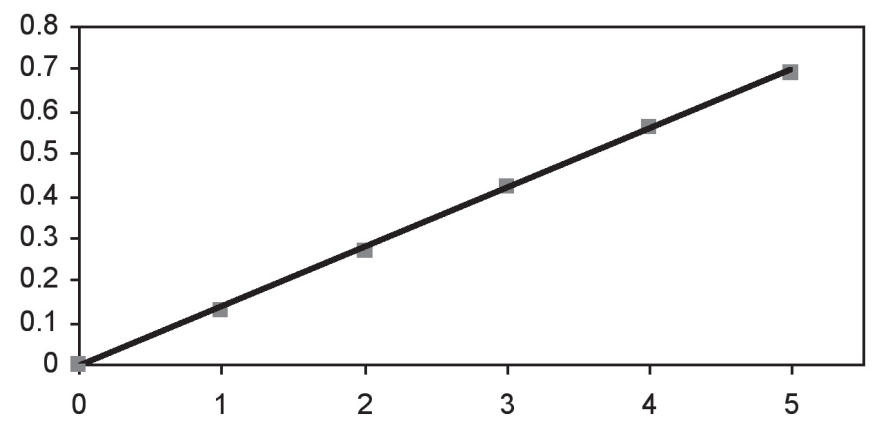

Concentration of drug, $\mu \mathrm{g} / \mathrm{ml}$

Fig 2. Beer's law curve for method A

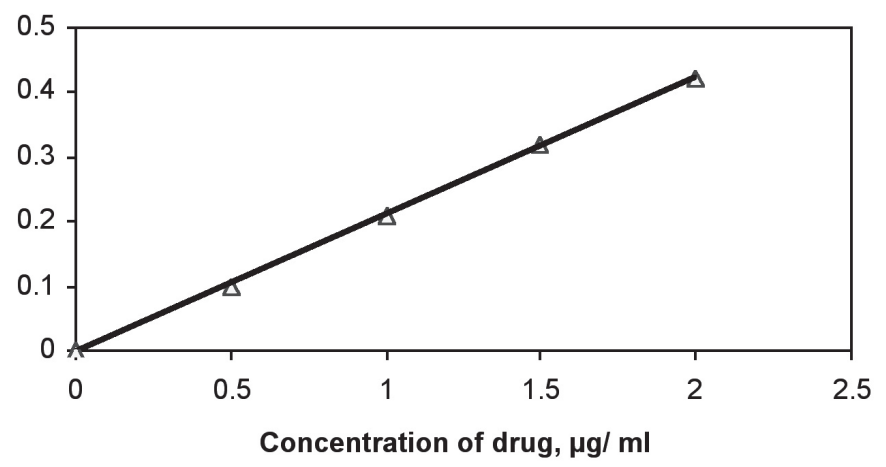

Fig 3. Beer's law curve for method B

Preliminary experiments were performed to fix the upper limits of the dyes that could be determined spectrophotometrically, and these were found to be 4 and $5 \mu \mathrm{g} \mathrm{mL}^{-1}$ for methylene blue and rhodamine B, respectively. A bromate concentration of $2.5 \mu \mathrm{g} \mathrm{mL}^{-1}$ was found to irreversibly destroy the blue colour of
$4 \mu \mathrm{g} \mathrm{mL}^{-1}$ methylene blue whereas $1.0 \mu \mathrm{g} \mathrm{mL}^{-1}$ bromate was required to bleach red colour due to $5 \mu \mathrm{g} \mathrm{mL}^{-1}$ rhodamine B. Hence, different concentrations of RLX were reacted with $1 \mathrm{~mL}$ of $25 \mu \mathrm{g} \mathrm{mL}^{-1}$ bromate in method A and $1 \mathrm{~mL}$ of $10 \mu \mathrm{g} \mathrm{mL}^{-1}$ bromate in method B followed by determination of the residual bromine as described under the respective procedures.

For both the steps, i.e. for the reaction between RLX and bromine, and for bleaching of dye by bromine, hydrochloric acid medium was found to be ideal. One $\mathrm{mL}$ of $5 \mathrm{M}$ hydrochloric acid in a total volume of $\sim 4-5 \mathrm{~mL}$ was adequate for the bromination step which was complete in $10 \mathrm{~min}$ in both methods and the same quantity of acid was employed for the estimation of the dye. Contact time of $10 \mathrm{~min}$ is not critical and any delay upto $20 \mathrm{~min}$ for method $\mathrm{A}$, and 30 min for method $\mathrm{B}$, will have no effect on the absorbance.

Table 2. Analytical and regression parameters of spectrophotometric Method

\begin{tabular}{|l|c|c|}
\hline \multicolumn{1}{|c|}{ Parameter } & Method A & Method B \\
\hline$\lambda_{\text {max }}, \mathrm{nm}$ & 665 & 555 \\
\hline Beer's law limits, $\mu \mathrm{g} \mathrm{mL}^{-1}$ & $0.5-5.0$ & $0.1-2.0$ \\
\hline Molar absorptivity, $\mathrm{L} \mathrm{mol}^{-1} \mathrm{~cm}^{-1}$ & $7.0 \times 10^{4}$ & $1.1 \times 10^{5}$ \\
\hline Sandell sensitivity, $\mu \mathrm{g} \mathrm{cm}^{-2}$ & 0.0073 & 0.0048 \\
\hline Limit of detection, $\mu \mathrm{g} \mathrm{mL}^{-1}$ & 0.06 & 0.04 \\
\hline Limit of quantification, $\mu \mathrm{g} \mathrm{mL}^{-1}$ & 0.18 & 0.13 \\
\hline Regression equation, $\mathrm{Y}^{*}$ & -0.0090 & -0.0050 \\
Intercept (a) & 0.1410 & 0.2140 \\
\hline Slope (b) & 0.9997 & 0.9997 \\
\hline Correlation coefficient, $(\mathrm{r})$ & 0.0061 & 0.0039 \\
\hline $\mathrm{S}_{\mathrm{a}}$ & 0.0019 & 0.0035 \\
\hline $\mathrm{S}_{\mathrm{b}}$ & & \\
\hline
\end{tabular}

$* \mathrm{Y}=\mathrm{a}+\mathrm{bX}$, where $\mathrm{Y}$ is the absorbance and $\mathrm{X}$ concentration in $\mu \mathrm{g} \mathrm{mL}^{-1}$ $\mathrm{S}=$ Standard deviation of intercept.

$\mathrm{S}_{\mathrm{b}}^{\mathrm{a}}=$ Standard deviation of slope.

\section{Method Validation}

Accuracy and precision

To evaluate the accuracy and precision of the methods, pure drug solution at three different levels (within the working limits) was analysed, each determination being repeated seven times. The relative error (\%) and relative standard deviation (\%) were less than 2.0 and indicate the high accuracy and precision for the methods (Table 3). For a better picture of reproducibility on a day-to-day basis, a series of experiments were performed in which standard drug solution at three different levels was determined each day for five days with all solutions being prepared afresh each day. The day-to-day relative standard deviation values were in the range of $2.2-2.7 \%$ and represent the best appraisal of the methods in routine use. These results are also given in Table 3.

Linear range, and regression and sensitivity parameters.

A linear correlation was found between absorbance at $\lambda_{\max }$ and concentration of RLX.

The graphs showed negligible intercept and are described by the equation:

$\mathrm{Y}=\mathrm{a}+\mathrm{bX}$

(Where $\mathrm{Y}=$ absorbance of 1 -cm layer of solution; $\mathrm{a}=$ intercept; $\mathrm{b}=$ slope and $\mathrm{X}=$ concentration in $\mu \mathrm{g} \mathrm{mL}^{-1}$ ). Regression analysis of the Beer's law data using the method of least squares was made to evaluate the slope (b), intercept (a) and correlation coefficient(r) for each system and the values are presented in Table 1. The optical characteristics such as Beer's law limits, molar absorptivity and Sandell sensitivity values of both methods are also given in Table 1 . The limits of detection (LOD) and quantitation(LOQ) calculated according to ICH guidelines ${ }^{22}$ are also presented in Table. 1 and reveal the very high sensitivity of the proposed methods. 
Table 3. Evaluation of accuracy and precision

\begin{tabular}{|c|c|c|c|c|c|c|c|}
\hline \multirow{3}{*}{ Method } & \multirow{2}{*}{$\begin{array}{c}\text { OLZ } \\
\text { Taken, } \\
\mu \mathrm{g} \\
\mathrm{mL}^{-1}\end{array}$} & \multicolumn{3}{|c|}{ Intra-day accuracy and precision } & \multicolumn{3}{|c|}{ Intra-day accuracy and precision } \\
\hline & & $\begin{array}{l}\text { RLX found } \\
\mu \mathrm{g} \mathrm{mL}^{-1}\end{array}$ & $\begin{array}{c}\mathrm{RE} \\
\%\end{array}$ & $\begin{array}{l}\mathrm{RSD} \\
\%\end{array}$ & $\begin{array}{l}\text { RLX found }{ }^{* *} \text {, } \\
\mu \mathrm{g} \mathrm{mL}^{-1}\end{array}$ & $\begin{array}{r}\mathrm{RE} \\
\%\end{array}$ & $\begin{array}{r}\mathrm{RSD} \\
\%\end{array}$ \\
\hline & 1.5 & 1.47 & 2.00 & 0.58 & 1.46 & 2.67 & 2.46 \\
\hline \multirow[t]{3}{*}{ A } & 2.5 & 2.49 & 0.4 & 0.62 & 2.43 & 2.80 & 2.20 \\
\hline & 3.5 & 3.45 & 1.43 & 0.74 & 3.43 & 2.00 & 2.64 \\
\hline & 0.5 & 0.49 & 2.00 & 1.04 & 0.48 & 2.00 & 2.58 \\
\hline \multirow[t]{2}{*}{ B } & 1.5 & 1.48 & 1.33 & 0.75 & 1.46 & 2.67 & 2.34 \\
\hline & 2.0 & 1.98 & 1.00 & 0.62 & 1.93 & 3.50 & 2.70 \\
\hline
\end{tabular}

RE relative error; RSD Relative standard deviation.

* Mean value of seven determinations

${ }^{* *}$ Mean value of five determinations

\section{Application to analysis of commercial samples}

In order to check the validity of the proposed methods, RLX was determined in some commercial formulations. Table 4 gives the results of the determination from which it is clear that there is a close agreement between the results obtained by the proposed methods and the label claim. The results were also compared with those of the reference method ${ }^{12}$ statistically by a Student's t- test for accuracy and variance ratio F- test for precision at $95 \%$ confidence level. The calculated t- and F-values (Table III) did not exceed the tabulated values $(t=2.77, F=6.39)$ four degrees of freedom and this would indicate that there was no significant difference between the proposed methods and the reference method with respect to accuracy and precision.

The accuracy and validity of the proposed methods were further ascertained by performing recovery studies. Pre-analysed tablet or capsule powder was spiked with pure RLX at three different levels and the total was found by the proposed methods. Each determination was repeated three times. The recovery of the pure drug added was quantitative and revealed that co-formulated substances such as crospovidone, FD and C Blue No.2 aluminum lake, hypromellose, lactose monohydrate, magnesium stearate, modified pharmaceutical glaze, polyethylene glycol, polysorbate 80 , povidone, propylene glycol, and titanium dioxide did not interfere in the determination. The results of recovery study are compiled in Table 5 .
Table 4. Results of determination of raloxifene hydrochloride in formulations and statistical comparison with the reference method

\begin{tabular}{|c|c|c|c|c|}
\hline \multirow{2}{*}{$\begin{array}{l}\text { Formulation } \\
\text { Brand } \\
\text { name }{ }^{\#}\end{array}$} & \multirow{2}{*}{$\begin{array}{l}\text { Nominal } \\
\text { amount, } \\
\text { mg }\end{array}$} & \multicolumn{3}{|c|}{$\%$ Found $* \pm S D$} \\
\hline & & $\begin{array}{l}\text { Reference } \\
\text { method }\end{array}$ & Method A & Method B \\
\hline FIONA $^{\mathrm{a}}$ & 60 & $100.3 \pm 0.46$ & $\begin{array}{l}99.8 \pm 1.05 \\
\mathrm{t}=1.05 \\
\mathrm{~F}=5.21\end{array}$ & $\begin{array}{l}101.1 \pm 1.03 \\
\mathrm{t}=1.70 \\
\mathrm{~F}=5.01\end{array}$ \\
\hline GYNISTA $^{\mathrm{b}}$ & 60 & $102.3 \pm 0.51$ & $\begin{array}{l}101.95 \pm 1.02 \\
\mathrm{t}=0.72 \\
\mathrm{~F}=4.00\end{array}$ & $\begin{array}{l}100.6 \pm 1.16 \\
t=3.22 \\
F=5.17\end{array}$ \\
\hline RONAL $^{c}$ & 60 & $101.2 \pm 0.65$ & $\begin{array}{l}99.95 \pm 1.02 \\
\mathrm{t}=2.37 \\
\mathrm{~F}=2.46\end{array}$ & $\begin{array}{l}101.9 \pm 1.33 \\
\mathrm{t}=1.12 \\
\mathrm{~F}=4.19\end{array}$ \\
\hline
\end{tabular}

* Mean value of five determinations

\#Marketed by: a. Reddy's Ltd. ; b. Micro(Nova) Ltd.; c. Blue cross Ltd.

Tabulated t-value at $95 \%$ confidence level is 2.77

Tabulated F-value at $95 \%$ confidence level is 6.39 . 
Table 5. Results of recovery experiments by standard addition method

\begin{tabular}{|c|c|c|c|c|c|c|c|c|}
\hline \multirow[b]{2}{*}{$\begin{array}{l}\text { Formulation } \\
\text { studied }\end{array}$} & \multicolumn{4}{|c|}{ Method A } & \multicolumn{4}{|c|}{ Method B } \\
\hline & $\begin{array}{l}\text { Amount } \\
\text { of drug in } \\
\text { tablet, } \mu \mathrm{g}\end{array}$ & $\begin{array}{l}\text { Amount of } \\
\text { pure drug } \\
\text { added, } \mu \mathrm{g}\end{array}$ & $\begin{array}{c}\text { Total } \\
\text { found, } \mu \mathrm{g}\end{array}$ & $\begin{array}{c}\text { Pure drug } \\
\text { recovered*, } \\
\%\end{array}$ & $\begin{array}{l}\text { Amount of drug } \\
\text { in tablet, } \mu \mathrm{g}\end{array}$ & $\begin{array}{l}\text { Amount of pure } \\
\text { drug added, } \mu \mathrm{g}\end{array}$ & $\begin{array}{c}\text { Total } \\
\text { found, } \mu \mathrm{g}\end{array}$ & $\begin{array}{c}\text { Pure drug } \\
\text { recovered } \\
\%\end{array}$ \\
\hline \multirow{2}{*}{ FIONA 60} & 4.990 & 5 & 10.07 & 101.5 & 5.055 & 5 & 10.19 & 102.6 \\
\hline & 4.990 & 20 & 25.49 & 102.5 & 5.055 & 10 & 15.01 & 99.5 \\
\hline \multirow{4}{*}{ RONAL 60} & 4.990 & 45 & 50.40 & 100.9 & 5.055 & 15 & 20.10 & 100.3 \\
\hline & 4.998 & 5 & 9.98 & 99.7 & 5.095 & 5 & 10.26 & 103.2 \\
\hline & 4.998 & 20 & 24.66 & 98.3 & 5.095 & 10 & 14.92 & 98.2 \\
\hline & 4.998 & 45 & 50.27 & 100.6 & 5.095 & 15 & 20.17 & 100.5 \\
\hline
\end{tabular}

*Mean value of three determinations

\subsection{CONCLUSIONS}

Two useful micro methods for the determination of RLX have been developed and validated. The methods are simple and rapid taking not more than 15-20 min for the assay. Both spectrophotometric methods are more sensitive than the existing UV and HPLC methods, and are free from such experimental variables as heating or extraction step. The methods rely on the use of simple and cheap chemicals and techniques but provide a sensitivity comparable to that achieved by sophisticated and expensive technique like HPLC. Thus, they can be used as alternatives for rapid and routine determination of bulk sample and tablets.

\section{REFERENCES}

1. The Merck Index, $12^{\text {th }}$ Edn., Merck and Co. Inc, White House Station. N J (1997) pp.1394.

2. Y. Jin, Huaxue Gongye Yu Gongcheng Jishu. 25, 56, (2004)

3. J. Trontelj, T. Vovk, M. Bogataj, A. Mrhar, Pharm. Res. 52, 334, (2005)

4. Q. Wang, H. Zhang, Z. Yu, Shenyang Yaoke Daxue Xuebao. 19, 105, (2002)

5. N. Pai, J. P. Wagh, Indian Drugs. 38, 591, (2001)

6. P. Venkata Reddy, B. Indha Ravi, G. Srinibabu, J.V.L.N. Sehagiri Rao, e-J Chem. 3, 60, (2006)

7. D. C. Pavithra, S. Lakshmo. India J. Pharm. Sci., 68, 401, (2006)

8. Y. Chen, Z. Lu, J. Zhang, Guangdong Yaoxueyuan Xuebao. 20, 109, (2004)
9. T. Perez-Ruiz, C. Martinez-Lozano, Sanz Antonio, Bravo Eva, J. Pharm. Biomed. Anal. 34, 891, (2004)

10. L. Fan, L. Shao-Pu, Y. Da-Cheng, Hu Xiao-Li, Chin J. Chem. 20, 1552, (2002)

11. J. Dharuman, V. Ravichandran, N. Thirumoorthy, A. Dharamsi, Pharmazie. 59, 720, (2004)

12. M. M. Annapurna, M. E. Bhanoji rao, B. V. V. Ravi Kumar, e-J. Chem. 4, 79, (2007)

13. K. Basavaiah, Indian J. Chem. Technol. 12, 25, (2005)

14. K. Basavaiah, U. Chandrashekar, Acta Ciencia Indica Chem. 29, 25 , (2003)

15. K. Basavaiah, P. Nagegowda, J. Braz. Chem. Soc. 16, 821, (2005)

16. K. Basavaiah, P. Nagegowda, IL Farmaco. 59, 147, (2004)

17. K. Basavaiah, P. Nagegowda, Oxid. Commun. 27, 186, (2004)

18. K. Basavaiah, H. C. Prameela, Science Asia. 29, 147, (2003)

19. K. Basavaiah, H. C. Prameela, Anal. Bioanal. Chem. 376, 879, (2003)

20. K. Basavaiah, H. C. Prameela, Indian J. Pharm. Sci. 67, 863, (2004)

21. K. Basavaiah, B. C. Somashekar, Indian J. Chem. Technol. 12, 316, (2006)

22. International Conference on Harmonization of Technical Requirements for Registration of Pharmaceuticals for Human Use, ICH Harmonised Tripartite Guideline, Validation of Analytical Procedures: Text and Methodology Q2(R1), Complementary Guideline on Methodology dated 06 November 1996, incorporated in November 2005, London. 